UDC 681.121.84

F. Matiko, DSc, Prof.,

I. Kostyk,

H. Matiko, PhD, Assoc. Prof.,

V. Roman, $\mathrm{PhD}$

Lviv Polytechnic National University, 12 S. Bandery Str., Lviv, Ukraine, 79013, e-mail: fedir.d.matiko@lpnu.ua

\title{
INVESTIGATING THE ADDITIONAL UNCERTAINTY OF FLOWRATE MEASUREMENT CAUSED BY SYMMETRICALLY DISTURBED FLOW
}

\begin{abstract}
Ф.Д. Матіко, І.В. Костик, Г.Ф. Матіко, В.І. Роман. Дослідження додаткової складової невизначеності результату вимірювання витрати, зумовленої симетричними спотвореннями профілю швидкості потоку. Під час застосування витратомірів в технологічних умовах часто виникають значні додаткові похибки вимірювання витрати внаслідок спотворення профілю швидкості потоку перед первинним перетворювачем витрати. Спотворення профілю швидкості потоку можуть бути сформовані, зокрема, концентричними виступами у трубопроводі. Метою цієї статті є дослідження впливу концентричних виступів, які формують симетричне спотворення профілю швидкості потоку перед стандартною діафрагмою, на невизначеність результату вимірювання витрати. Дослідження додаткової складової невизначеності виконане експериментальним методом. Для цього розроблено установку, до складу якої входять два послідовно встановлені витратоміри змінного перепаду тиску, зразковий та робочий, 3 внутрішнім діаметром $D=0,1$ м. Вплив виступів досліджено за допомогою встановлення концентричних кілець, що імітують виступ висотою $h=0,025 D, 0,05 D, 0,1 D$. Експериментальні дослідження виконано для стандартних діафрагм 3 відносним діаметром отвору $\beta=0,2 ; 0,4 ; 0,5 ; 0,67$ за умови наявності виступу на відстані $L=2 D, 5 D, 10 D$ перед діафрагмою. За результатами експериментальних досліджень обчислено значення відносного відхилення коефіцієнта витікання діафрагми $\delta_{C p}$, зумовленого наявністю концентричного виступу перед діафрагмою. Підтверджено, що для розвинутого турбулентного режиму руху потоку залежність відносного відхилення $\delta_{C p}$ від числа Рейнольдса є близькою до лінійної, тому вплив висоти виступу для кожного фіксованого значення $h$ та $L$ може бути відтворений усередненим значенням відносного відхилення. Розроблено аналітичні залежності для обчислення усередненого відносного відхилення від конструктивних характеристик витратоміра та запропоновано оцінювати додаткову розширену невизначеність вимірюваного значення витрати за цими залежностями. Застосування результатів роботи дає можливість оцінити невизначеність результату вимірювання витрати у технологічних умовах, а, відповідно, оцінити можливість застосування витратомірів з наявними додатковими складовими невизначеності.

Ключові слова: витратомір змінного перепаду тиску, діафрагма, коефіцієнт витікання, профіль швидкості потоку, концентричний виступ, додаткова невизначеність
\end{abstract}

F. Matiko, I Kostyk, H. Matiko, V. Roman. Investigating the additional uncertainty of flowrate measurement caused by symmetrically disturbed flow. When flowmeters are used in technological conditions significant additional errors in flow measurement are often caused by distortion of the flow velocity profile upstream the primary device. The distortion of the flow velocity profile can be caused, particularly, by concentric protrusions in the pipeline. The purpose of this paper is to investigate the effect of concentric protrusions, which form a symmetric flow distortion upstream the standard orifice plate, on the uncertainty of flow measurement result. The additional component of uncertainty was studied experimentally. For this purpose a setup was developed consisting of two series-installed differential pressure flowmeters, a reference and a test one, with an inner diameter $D=0.1 \mathrm{~m}$. The effect of the protrusions was investigated by installing concentric rings that imitate the protrusion height $h=0.025 D, 0.05 D, 0.1 D$. Experimental studies were performed for standard orifice plate with relative diameter $\beta=0.2 ; 0.4 ; 0.5 ; 0.67$ provided that there is a protrusion at a distance $L=2 D, 5 D, 10 D$ upstream the orifice plate. According to the results of experimental studies the authors calculated the values of the relative deviation of the orifice plate discharge coefficient $\delta_{C p}$ caused by the concentric protrusion upstream the orifice plate. It is confirmed that the dependence of the relative deviation $\delta_{C p}$ versus the Reynolds number is close to linear for the developed turbulent flow, so the effect of the protrusion height for each fixed value of $h$ and $L$ can be reproduced by the mean relative deviation. Analytical dependencies are developed to calculate the mean relative deviation from the design characteristics of flowmeter and the additional expanded uncertainty of measured flowrate is proposed to be evaluated by these dependencies. Applying the results of the paper makes it possible to evaluate the uncertainty of flow measurement in technological conditions and, respectively, to determine the possibility of using flowmeters with available additional components of uncertainty. uncertainty

Keywords: differential pressure flowmeter, orifice plate, discharge coefficient, flow velocity profile, concentric protrusion, additional

\section{Introduction}

Automated flow measurement systems are an important component of many technological complexes. They provide measurement of fluids flowrate and volume at the inputs and outputs of techno- 
logical complexes, as well as forming the material balance and evaluating the efficiency of technological processes, including energetics [1].

Flowmeters based on throttle elements, in particular flowmeters with standard orifice plates are the basis of many automated flow measurement systems [2]. However, when using these flowmeters in conditions of technological plants, it is not always possible to meet the requirements of the standards for their design and installation. As a result additional errors of flow measurement occur that influence the measurement result of flowrate and volume, as well as the balance of fluid energy carrier in the system. Therefore, the urgent task is to investigate the additional errors of differential pressure flowmeters and to develop suggestions for their reducing.

In particular, additional errors of flow measurement may occur due to distortion of the flow velocity profile upstream the primary device. The distortion of the flow may be caused by local fittings or by some pipeline elements, including symmetrical inner protrusions of the pipeline. Examples of such symmetrical protrusions are protruding gaskets between the flanges or between the flanges and the carrier rings, concentric protruding welds. This article is devoted to studying the additional errors of flow measurement caused by such symmetrical protrusions.

\section{Analysis of recent publications}

A detailed analysis of characteristics of differential pressure flowmeters was made due to the implementing the standards DSTU GOST 8.586.1-5:2009. For flowmeters designed according to the old normative documents, the implementation of these standards requires a whole set of measures: changes in geometric characteristics of measuring pipeline and primary device according to DSTU GOST 8.586.1,2:2009 as well as changes in flowrate calculating algorithm according to DSTU GOST 8.586.5:2009 [3]. Sometimes the non-compliance with the requirements of DSTU GOST 8.586.15:2009 only belongs to the individual characteristics of measuring pipeline or primary device. When studying the current flow measurement systems, the authors found that following features of flowmeters design are most common in their operation practice and lead to additional uncertainty:

- protrusions, recesses, inner gaskets protruding into the pipeline and placed within the pipeline section length of $10 D$ upstream the orifice plate;

- deviation of the pipeline cylindricality;

- sections with heterogeneous roughness within the pipeline section length of $10 D$ upstream the orifice plate;

- reducing the length of straight sections of measuring pipelines upstream the orifice plate.

Many research papers and guidelines, particularly [4-7], have confirmed that recesses (concentric slits) in the $2 D$ long section upstream and downstream the orifice plate are not impact factors that cause significant flow distortions. On the contrary, inner protrusions in pipeline can cause significant errors in flow measurement. In particular, researches [4-7] present the results of the protrusions effect at a distance of less than $2 D$ upstream the orifice plate and confirm that such protrusions can have a significant effect on its discharge coefficient. However, the effect of protrusions at distances up to $10 D$ upstream the orifice plate has not been investigated.

The protrusions immediately upstream the orifice plate cause the most significant deviations of the discharge coefficient, depending on the protrusion size and the relative diameter $\beta$ of the orifice plate [5]. In particular, the effect of the protrusions at $\beta=0.5$ should be taken into account already at the protrusion height more than $1.0 \% \mathrm{D}$. In particular, deviations of the discharge coefficient reach the value of $11.5 \%$ at the height of the protrusion of $12.5 \% D$. The effect of the protrusions at $\beta=0.7$ is even greater and the protrusions should be avoided or equal below $0.38 \% D$ in order to provide the deviation of the discharge coefficient within its uncertainty [5].

Experimental data on changing the orifice plate discharge coefficient installed in the measuring pipeline with the shortened straight sections are presented in papers [8-10] and systematized in ISO/TR 12767:2007 [4]. These data allow us to evaluate the additional uncertainty of the measured flowrate for different measuring pipeline configurations.

Therefore, as the results of scientific and technical literature analysis on the effect of design features of pressure differential flowmeters on the flow measurement error the authors concluded that 
protrusions effect on the flow measurement result may be significant and has not been investigated for ranges of geometric dimensions of test flowmeters.

The purpose of the work is to investigate the effect of concentric protrusions, which form a symmetric flow distortion upstream the standard orifice plate, on the flowrate measurement result. Such studies make it possible to evaluate the uncertainty of the measured value of gas flowrate and to conclude that a specific fluid flow measurement system can be used.

\section{Description of the experimental setup}

Investigating the additional errors of flowmeters can be performed both experimentally and by mathematical modeling methods. However, the results presented in many papers show that applying the mathematical modeling methods is effective only if the mathematical model is verified or refined based on experimental data.

To perform experimental studies of additional errors of gas flowmeters a flow measuring setup was developed at Lviv Polytechnic National University, which consists of two differential pressure flowmeters: reference and test (see Fig. $1 \mathrm{a}$ ). Both flowmeters have high-precision measuring transducers of pressure drop, pressure, temperature made by Honeywell with output HART signal (see Fig. $1 b$ ). Flow calculating is performed in real time using the program installed on the PC.

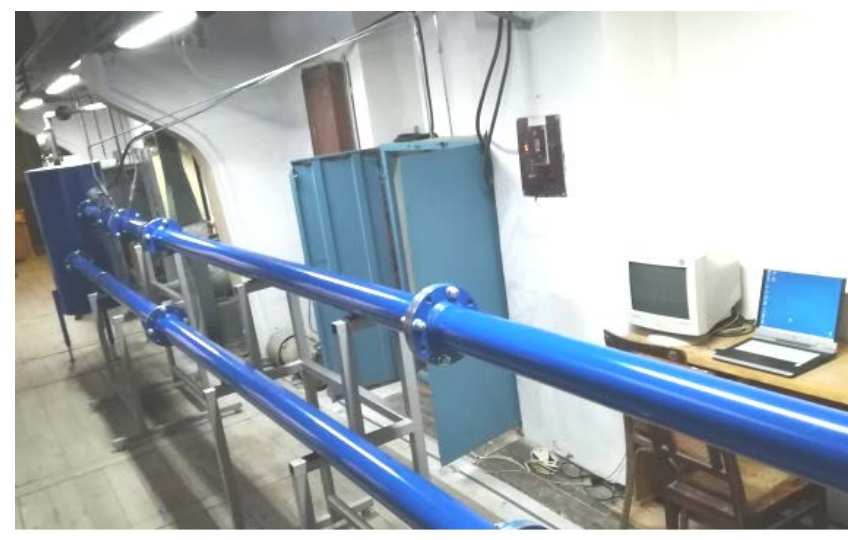

$a$

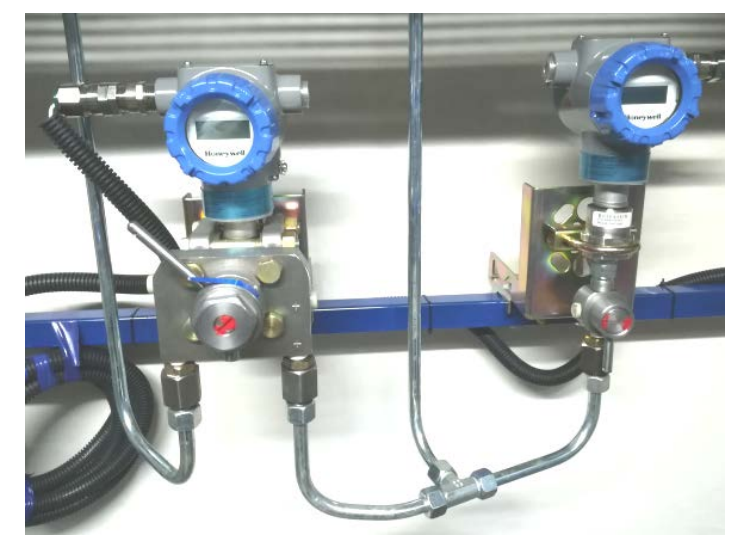

$b$

Fig. 1. Experimental setup: general view (a); panel with measuring transducers (b)

The experimental setup has the following basic characteristics: the inner diameter of the pipeline is $0.1 \mathrm{~m}$; the straight length of measuring pipeline upstream reference and test flowmeters are more than $100 D$; environment - air up to $0.2 \mathrm{bar}$; range of air flowrate is $50 \ldots 1000 \mathrm{~m}^{3} / \mathrm{h}$ (at reference conditions).

The design of the first (reference) flowmeter and the geometric dimensions of its elements meet the requirements of DSTU GOST 8.586.1,2,5:2009. The second (test) flowmeter has an element with geometric dimensions that are beyond the limits set in DSTU GOST 8.586.1,2,5:2009. So it forms a distortion of the flow velocity profile.

All sections of the measuring pipeline installed upstream and downstream the orifice plates of reference flowmeter and test flowmeter are made of cold-drawn steel seamless pipe 120×100 H8. It has the following characteristics: deviation tolerance of the internal diameter H8 according to GOST 25347-2013 (ISO 286-2-2013) (ISO 286-2-2013); a roughness of the inner surface Ra not more than 0.4 microns; straightness - the local deviation does not exceed $1 \mathrm{~mm}$ for every meter of length. This provides the conditions for non-distorted flow upstream the flowmeters.

Compliance of the geometric dimensions of the measuring pipeline of reference and test flowmeters with the requirements of DSTU GOST 8.586.1,2:2009 was checked by DP "Lvivstandartmetrologiya" according to the method of MVU 043/01-2011. This fact is confirmed by the protocols of measurements of the geometric dimensions of measuring pipeline of reference and test flowmeters.

To allow the investigating of the effect of the inner protrusion in the pipeline on the measured value of flowrate at different distances from the orifice plate, the section of measuring pipeline of test 
flowmeter with length $10 D$ upstream the orifice plate consists of three sections: section with length $2 D$, section with length $3 D$ and section with length $5 D$.

Experimental research were performed for standard orifice plates with relative diameter $\beta=0.2$; $0.4 ; 0.5 ; 0.67$. The actual values of the relative diameter $\beta$ obtained on the basis of the values of the bore diameter that is measured in accordance with the requirements of MVU 043/01-2011 are presented in Table 1.

Table 1

The values of the relative diameters $\beta$ of orifice plate used for the experimental research

\begin{tabular}{c|c|c|c|c|c|c}
\hline \multirow{2}{*}{ № } & \multicolumn{3}{|c|}{ Reference flowmeter } & \multicolumn{3}{c}{ Test flowmeter } \\
\cline { 2 - 7 } & $\begin{array}{c}\text { № of the orifice } \\
\text { plate }\end{array}$ & $\begin{array}{c}\text { Bore } \\
\text { diameter } \\
d_{20}, \mathrm{~mm}\end{array}$ & $\begin{array}{c}\text { Relative di- } \\
\text { ameter } \beta^{*}\end{array}$ & $\begin{array}{c}\text { № of the ori- } \\
\text { fice plate }\end{array}$ & $\begin{array}{c}\text { Bore diameter } \\
d_{20}, \text { mm }\end{array}$ & $\begin{array}{c}\text { Relative } \\
\text { diameter } \beta^{*}\end{array}$ \\
\hline 1 & $46-1$ & 19.993 & 0.200070 & $47-1$ & 19.982 & 0.200160 \\
\hline 2 & $46-2$ & 39.987 & 0.400150 & $47-2$ & 39.99 & 0.400581 \\
\hline 3 & $46-3$ & 49.995 & 0.500300 & $47-3$ & 49.992 & 0.500771 \\
\hline 4 & $46-4$ & 66.987 & 0.670339 & $47-4$ & 66.978 & 0.670921 \\
\hline
\end{tabular}

Calculating of the air flowrate is realized in real time on the basis of the measured values of pressure drop, absolute pressure, temperature according to the algorithm that meets the requirements of GOST 8.586.5:2009 [3]. The program for flowrate calculating is realized using PC, which with the help of HART-modem realizes a polling of measuring transducers of pressure drop, absolute pressure, temperature for reference and test flowmeters respectively. The compliance of the flowrate calculating algorithm realized by the PC with the requirements of DSTU GOST 8.586.5:2009 was verified by comparing the results calculated by the program with the flowrate results obtained by CAD "RashodRU” (version 3.0) for test combinations of input data.

Archives of instant values of pressure drop, absolute pressure, temperature, air flowrate under reference conditions for reference and test flowmeters were obtained by using the measurement results. The results of processing the archives of instant values of air parameters and its flowrate are the basis for determining additional components of uncertainty of the measured value of flowrate.

\section{Processing the experimental results}

In order to investigate the effect of the protrusion a ring is installed into the inner cavity of the pipeline between the sections of the measuring pipeline of the test flowmeter that imitates the protrusion. The research program provides the experimental studies for rings with a thickness of $8 \mathrm{~mm}$, imitating the protrusion height of $0.025 D, 0.05 D, 0.1 D$. The study was performed with a ring-imitator installed at the distance of $2 D, 5 D, 10 D$ upstream the orifice plate.

Based on the experimental results, the value of the relative deviation of the flowrate caused by the effect of the inner protrusions in the pipeline is obtained:

$$
\delta_{Q}=\frac{\bar{Q}_{\text {test }}-\bar{Q}_{\text {ref }}}{\bar{Q}_{\text {ref }}} \cdot 100 \%,
$$

where $\bar{Q}_{\text {test }}, \bar{Q}_{\text {ref }}$ are the average value of the flowrate obtained during the experiment according to the measurement results of test and reference flowmeters respectively.

According to the experimental results, an array of relative deviations of the flowrate $\delta_{Q}$ was obtained for each value of the relative diameter $\beta$. In particular, for the orifice plate with a relative diameter $\beta=0.67$ the flow deviation array is presented in Table 2 .

\footnotetext{
${ }^{*}$ - is calculated for the bore diameters of the orifice plates and the inner diameter of the pipeline at $20^{\circ} \mathrm{C}$.
} 
Comparing the flowrate measurement results by reference and test flowmeters for the orifice plate with bore relative diameter $\beta=0.67$

\begin{tabular}{|c|c|c|c|c|c|c|c|c|}
\hline \multirow{2}{*}{ № } & \multirow{2}{*}{$\begin{array}{l}\text { Distance to up- } \\
\text { stream face of } \\
\text { carrier ring “+” }\end{array}$} & \multirow{2}{*}{$\begin{array}{c}\text { Protrusion } \\
\text { height }\end{array}$} & \multicolumn{6}{|c|}{ Relative deviation $\delta_{Q}(\%)$ for flow source mode } \\
\hline & & & 1 & 2 & 3 & 4 & 5 & 6 \\
\hline \multicolumn{3}{|c|}{ Reynolds number Re } & 96621 & 119814 & 133172 & 148645 & 164063 & 178943 \\
\hline 1 & Flowmeters with & protrusions & -0.313 & -0.081 & -0.193 & -0.286 & -0.21 & -0.208 \\
\hline 2 & \multirow{3}{*}{$L=2 D$} & $h=0.025 D$ & -0.646 & -0.261 & -0.516 & $\begin{array}{l}-0.498 \\
\end{array}$ & $\begin{array}{l}-0.466 \\
\end{array}$ & -0.450 \\
\hline 3 & & $h=0.05 D$ & -1.067 & -0.725 & -0.884 & -0.881 & -0.813 & -0.829 \\
\hline 4 & & $h=0.1 D$ & -3.853 & -3.451 & -3.666 & -3.645 & -3.560 & -3.540 \\
\hline 5 & \multirow{3}{*}{$L=5 D$} & $h=0.025 D$ & -0.429 & -0.179 & -0.336 & -0.363 & -0.283 & -0.319 \\
\hline 6 & & $h=0.05 D$ & 0.024 & 0.352 & 0.153 & 0.130 & 0.237 & 0.208 \\
\hline 7 & & $h=0.1 D$ & 1.192 & 1.460 & 1.292 & 1.256 & 1.292 & 1.326 \\
\hline 8 & \multirow{3}{*}{$L=10 D$} & $h=0.025 D$ & -0.327 & -0.108 & -0.250 & -0.304 & -0.210 & -0.233 \\
\hline 9 & & $h=0.05 D$ & 0.241 & 0.450 & 0.296 & 0.251 & 0.290 & 0.339 \\
\hline 10 & & $h=0.1 D$ & 1.147 & 1.350 & 1.182 & 1.151 & 1.226 & 1.170 \\
\hline
\end{tabular}

In order to obtain the effect of the protrusion on the measured value of the flowrate, the systematic deviations obtained for flowmeters without ring-imitators $\delta_{Q 0}$ (line 1 in Table 2) are excluded from the values of the relative deviation $\delta_{Q}$ obtained by studying the test flowmeter with installed ringimitator (lines 2-10 in Table 2). Thus an array of relative deviations of flowrate is obtained:

$$
\delta_{Q p}=\delta_{Q}-\delta_{Q 0},
$$

that correspond to the effect of the inner protrusion in the pipeline on the measured value of flowrate (see Table 3).

Table 3

Relative deviation of flowrate $\delta_{Q p}$ for the orifice plate with bore relative diameter $\beta=0.67$

\begin{tabular}{|c|c|c|c|c|c|c|c|c|c|}
\hline \multirow[b]{2}{*}{ № } & \multirow{2}{*}{$\begin{array}{l}\text { Distance to } \\
\text { upstream } \\
\text { face of car- } \\
\text { rier ring “+” }\end{array}$} & \multirow{2}{*}{$\begin{array}{l}\text { Protrusion } \\
\text { height }\end{array}$} & \multicolumn{6}{|c|}{ Relative deviation $\delta_{Q p}(\%)$ for flow source mode } & \multirow{2}{*}{$\begin{array}{l}\text { Mean de- } \\
\text { viation, } \\
\delta_{Q p m}, \%\end{array}$} \\
\hline & & & 1 & 2 & 3 & 4 & 5 & 6 & \\
\hline & \multicolumn{2}{|c|}{ Reynolds number Re*1e-5 } & 0.97 & 1.20 & 1.33 & 1.49 & 1.64 & 1.79 & \\
\hline 1 & \multirow{3}{*}{$L=2 D$} & $h=0.025 D$ & -0.333 & -0.18 & -0.323 & -0.212 & -0.256 & -0.242 & -0.258 \\
\hline 2 & & $h=0.05 D$ & -0.754 & -0.644 & -0.691 & -0.595 & -0.603 & -0.621 & -0.651 \\
\hline 3 & & $h=0.1 D$ & -3.54 & -3.37 & -3.473 & -3.359 & -3.35 & -3.332 & -3.404 \\
\hline 4 & \multirow{3}{*}{$L=5 D$} & $h=0.025 D$ & -0.116 & -0.098 & -0.143 & -0.077 & -0.073 & -0.111 & -0.103 \\
\hline 5 & & $h=0.05 D$ & 0.337 & 0.433 & 0.346 & 0.416 & 0.447 & 0.416 & 0.399 \\
\hline 6 & & $h=0.1 D$ & 1.505 & 1.541 & 1.485 & 1.542 & 1.502 & 1.534 & 1.518 \\
\hline 7 & \multirow{3}{*}{$L=10 D$} & $h=0.025 D$ & -0.014 & -0.027 & -0.057 & -0.018 & 0 & -0.025 & -0.024 \\
\hline 8 & & $h=0.05 D$ & 0.554 & 0.531 & 0.489 & 0.537 & 0.5 & 0.547 & 0.526 \\
\hline 9 & & $h=0.1 D$ & 1.46 & 1.431 & 1.375 & 1.437 & 1.436 & 1.378 & 1.420 \\
\hline
\end{tabular}

The dependencies of the relative deviation $\delta_{Q p}$ versus the Reynolds number Re for the corresponding straight length of measuring pipeline between the face of the carrier ring "+" and the crosssection of the ring-imitator are shown in Fig. $2 a, b$.

We can see from Fig. $2 a, b$, that the dependence $\delta_{Q p}=f(\mathrm{Re})$ is close to linear for the investigated values of the protrusion height $h$, the section length $L$ and the corresponding value of the relative diameter $\beta=0.67$. The change in the value $\delta_{Q p}$ is insignificant when the Reynolds number Re changes, so the effect of the protrusion height for each fixed value $h$ and $L$ can be reproduced by the mean deviation $\delta_{Q p m}$ calculated as the arithmetic mean of $\delta_{Q p}(\mathrm{Re})$ for the corresponding value $h$ (see Table 3 ). 

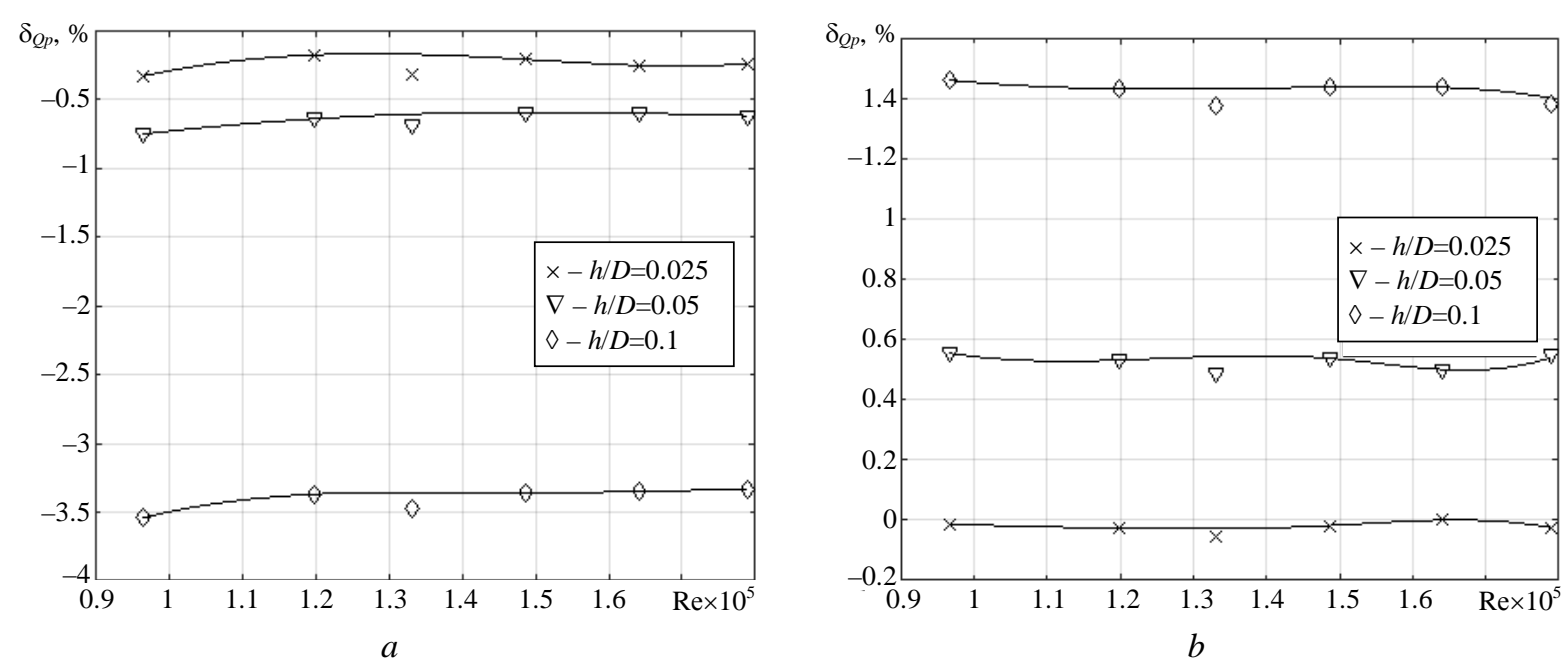

Fig. 2. The dependencies of relative deviation $\delta_{\mathrm{Qp}}$ versus Reynolds number Re for the straight lengths of measuring pipeline between the face of carrier ring "+ "and the ring-imitator of protrusion:

$$
L=2 D(a) ; L=10 D(b)
$$

The results of experimental studies for orifice plates with bore relative diameter $\beta=0.2 ; 0.4 ; 0.5$ were worked out similar to $\beta=0.67$. The arrays of the relative deviation $\delta_{Q p}$ for these orifice plates are formed.

It is obvious from the physical nature of the flow equation of the differential pressure method and the coefficients of this equation that the element in the inner cavity, which distorts the flow, leads to a change in the discharge coefficient of the primary device. This fact is confirmed by a large number of theoretical and experimental researches, including works [5-11]. Therefore, the deviation of the discharge coefficient caused by concentric protrusion upstream the orifice plate should be evaluated based on the obtained experimental results.

The relative deviation of the discharge coefficient should be determined by the formula:

$$
\delta_{C}=\frac{C-C_{0}}{C_{0}} \cdot 100 \%=\left(\frac{C}{C_{0}}-1\right) \cdot 100 \%,
$$

where $C$ is the discharge coefficient calculated for the values of the flow parameters in the measuring pipeline of test flowmeter; $C_{0}$ is the discharge coefficient calculated for the values of flow parameters in the measuring pipeline of the reference flowmeter.

From the equation of flow reduced to standard conditions (equation (5.8) DSTU GOST 8.586.5:2009 [3]) an expression was obtained to calculate the discharge coefficient using the results of experimental studies:

$$
C=\frac{q_{r c} \cdot\left(\rho_{r c} p_{r c} T K\right)^{0.5}}{0.25 \pi d^{2} E K_{R} K_{e s} \varepsilon\left(2 \Delta p \cdot p \cdot T_{r c}\right)^{0.5}},
$$

where $q_{r c}$ is the volumetric flowrate of fluid, reduced to reference conditions; $d$ is the diameter of orifice plate bore; $\varepsilon$ is the flow expansion coefficient; $E$ is the entry speed coefficient; $K$ is the compressibility coefficient of gas; $K_{e s}$ is the correction factor that takes into account the inlet edge sharpness of the orifice plate; $K_{R}$ is the correction factor that takes into account the roughness of the inner surface of the measuring pipeline; $\Delta p$ is the pressure drop on the primary device; $p$ is the fluid pressure; $T$ is the fluid absolute (thermodynamic) temperature; $p_{r c}, T_{r c}$, $\rho_{r c}$ are pressure, temperature and density of fluid under reference conditions, respectively.

It is necessary to calculate the ratio of the discharge coefficients in order to determine the relative deviation $\delta_{\mathrm{C}}$, which makes it possible to reduce the parameters and the coefficients that acquire the 
same values or differ slightly. Then from (3) and (4) we obtain the following formula for calculating the relative deviation of the discharge coefficient:

$$
\delta_{C}=\left[\frac{(T K)^{0.5} \cdot\left(d_{0}^{2} E_{0} \varepsilon_{0}\left(\Delta p_{0} \cdot p_{0}\right)^{0.5}\right)}{\left(T_{0} K_{0}\right)^{0.5} \cdot\left(d^{2} E \varepsilon(\Delta p \cdot p)^{0.5}\right)}-1\right] \cdot 100 \% .
$$

The index "0" in formula (5) indicates the characteristics and parameters related to the reference flowmeter.

The calculation of the deviation of the discharge coefficient was performed using the experimental values of the flow parameters by the following method:

1) formula (5) is applied to calculate the relative deviation for each set of instant values of the flow parameters in the measuring pipelines for test and reference flowmeters;

2) mean relative deviation for each investigated time interval for fixed flowrate was obtained by processing the arrays of relative deviation $\delta_{C}$;

3) mean relative deviation $\delta_{C}$ for each time interval during which the flowrate was constant are summarized in tables similar to the Table 2;

4) in order to investigate the effect of the protrusion on the discharge coefficient, the systematic deviations obtained for flowmeters without ring-imitators $\delta_{C o}$ are excluded from the values of the relative deviation $\delta_{C}$ obtained by studying the test flowmeter with installed ring-imitator. Thus, an array of relative deviations of the discharge coefficient $\delta_{C p}$ (see Table 4) was obtained corresponding to the effect of the inner protrusion in pipeline on the discharge coefficient.

In particular, for an orifice plate with relative diameter $\beta=0.67$, the deviation value $\delta_{C p}$ is presented in Table 4 . The mean relative deviation $\delta_{C p m}$ is obtained as the arithmetic mean value of $\delta_{C p}(\mathrm{Re})$ for the corresponding value $h$.

Table 4

Relative deviation of flowrate $\delta_{C p}$ for the orifice plate with the bore relative diameter $\beta=0.67$

\begin{tabular}{|c|c|c|c|c|c|c|c|c|c|}
\hline \multirow[b]{2}{*}{ № } & \multirow{2}{*}{$\begin{array}{l}\text { Distance to } \\
\text { upstream } \\
\text { face of car- } \\
\text { rier ring “+” }\end{array}$} & \multirow{2}{*}{$\begin{array}{c}\text { Protrusion } \\
\text { height }\end{array}$} & \multicolumn{6}{|c|}{ Relative deviation $\delta_{C p}(\%)$ for flow source mode } & \multirow{2}{*}{$\begin{array}{c}\text { Mean de- } \\
\text { viation, } \\
\delta_{C p m}, \%\end{array}$} \\
\hline & & & 1 & 2 & 3 & 4 & 5 & 6 & \\
\hline \multicolumn{3}{|c|}{ Reynolds number Re*1e-5 } & 0.97 & 1.20 & 1.33 & 1.49 & 1.64 & 1.79 & \\
\hline 1 & \multirow{3}{*}{$L=2 D$} & $h=0.025 D$ & 0.385 & 0.171 & 0.357 & 0.214 & 0.279 & 0.25 & 0.276 \\
\hline 2 & & $h=0.05 D$ & 0.793 & 0.647 & 0.707 & 0.607 & 0.619 & 0.629 & 0.667 \\
\hline 3 & & $h=0.1 D$ & 3.731 & 3.512 & 3.657 & 3.528 & 3.518 & 3.484 & 3.572 \\
\hline 4 & \multirow{3}{*}{$L=5 D$} & $h=0.025 D$ & 0.164 & 0.112 & 0.139 & 0.094 & 0.077 & 0.085 & 0.112 \\
\hline 5 & & $h=0.05 D$ & -0.325 & -0.438 & -0.342 & -0.424 & -0.437 & -0.425 & -0.398 \\
\hline 6 & & $h=0.1 D$ & -1.512 & -1.534 & -1.485 & -1.534 & -1.493 & -1.517 & -1.513 \\
\hline 7 & \multirow{3}{*}{$L=10 D$} & $h=0.025 D$ & 0.025 & 0.01 & 0.071 & 0.044 & 0.016 & 0.027 & 0.032 \\
\hline 8 & & $h=0.05 D$ & -0.513 & -0.538 & -0.497 & -0.523 & -0.522 & -0.549 & -0.524 \\
\hline 9 & & $h=0.1 D$ & -1.454 & -1.388 & -1.365 & -1.425 & -1.415 & -1.367 & -1.402 \\
\hline
\end{tabular}

The dependencies of the relative deviation $\delta_{C p}$ versus the Reynolds number Re for the corresponding straight length of measuring pipeline between the face of carrier ring "+" and the cross section of the ring-imitator are shown in Fig. $3 a, b$.

We can see from Table 4, Fig. $3 a, b$ that the values of $\delta_{C p}$ are close in modulus and opposite in sign to the deviations of the flowrate, which corresponds to the physical processes occurring in the flowmeters. The dependence $\delta_{C p}=f(\mathrm{Re})$ is close to linear for the investigated values of the protrusion height $h$, the section length $L$ and the corresponding value of the relative diameter $\beta=0.67$. The change in the value $\delta_{C p}$ is insignificant when the Reynolds number Re changes, so the effect of the protrusion height for each fixed value $h$ and $L$ can be reproduced by the mean deviation $\delta_{C p m}$ (see Table 4). 

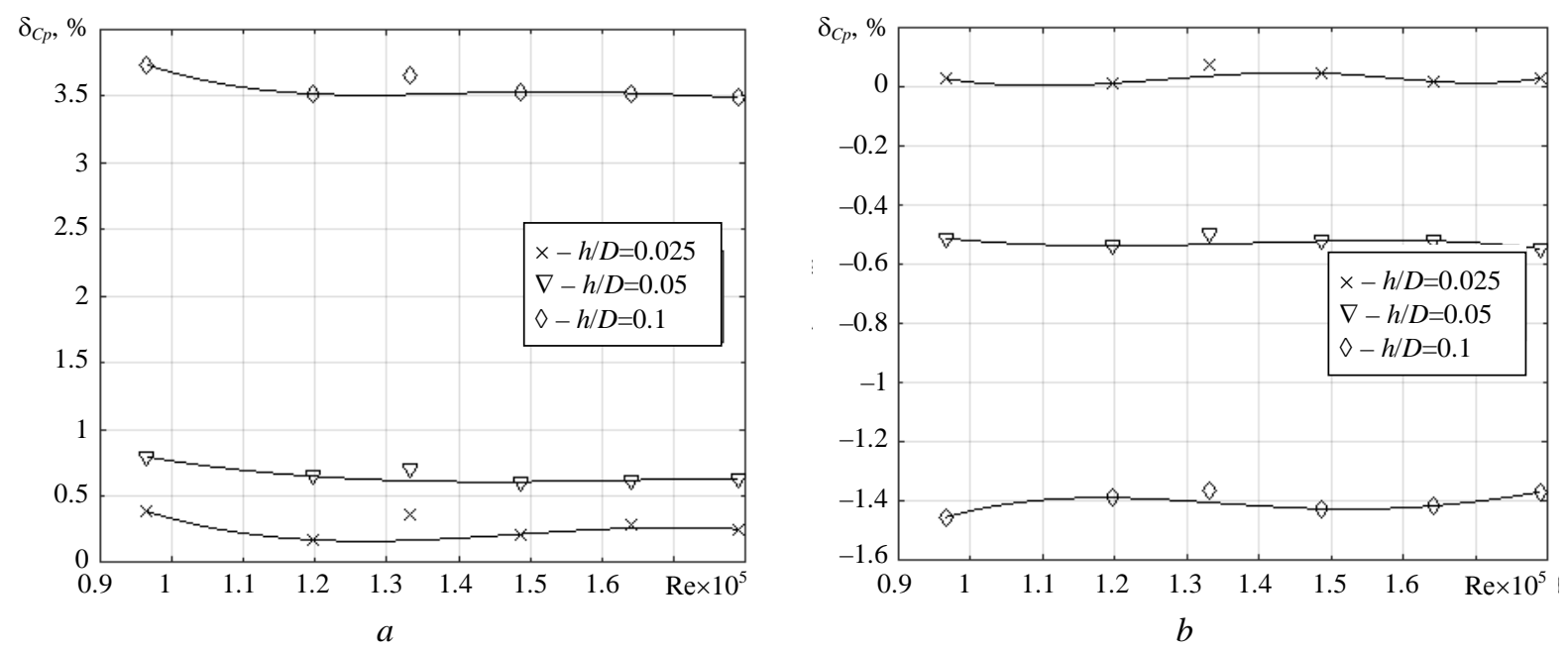

Fig. 3. The dependencies of mean deviation $\delta_{C p}$ versus Reynolds number Re for the straight length of measuring pipeline between the face of carrier ring "+ "and the ring-imitator of protrusion: $L=2 D(a) ; L=10 D(b)$

The results of experimental studies for orifice plates with bore relative diameter $\beta=0.2 ; 0.4 ; 0.5$ were worked out similar to $\beta=0.67$. The mean relative deviation $\delta_{C p m}$ are presented in Table 5 .

Table 5

Mean relative deviation $\delta_{C p m}$ for the investigated values $\beta$

\begin{tabular}{|c|c|c|c|c|c|c|}
\hline \multirow[b]{2}{*}{ № } & \multirow{2}{*}{$\begin{array}{l}\text { Distance to } \\
\text { upstream } \\
\text { face of car- } \\
\text { rier ring "+" }\end{array}$} & \multirow{2}{*}{$\begin{array}{c}\text { Protrusion } \\
\text { height }\end{array}$} & \multicolumn{4}{|c|}{ Mean relative deviation $\delta_{C p m}(\%)$ for relative diameter $\beta$} \\
\hline & & & 0.2 & 0.4 & 0.5 & 0.67 \\
\hline 1 & \multirow{3}{*}{$L=2 D$} & $h=0.025 D$ & 0.008 & 0.063 & 0.144 & 0.276 \\
\hline 2 & & $h=0.05 D$ & 0.050 & 0.253 & 0.431 & 0.667 \\
\hline 3 & & $h=0.1 D$ & 0.108 & 1.031 & 1.848 & 3.572 \\
\hline 4 & \multirow{3}{*}{$L=5 D$} & $h=0.025 D$ & -0.004 & 0.028 & 0.021 & 0.112 \\
\hline 5 & & $h=0.05 D$ & -0.014 & -0.023 & -0.134 & -0.398 \\
\hline 6 & & $h=0.1 D$ & -0.002 & -0.218 & -0.527 & -1.513 \\
\hline 7 & \multirow{3}{*}{$L=10 D$} & $h=0.025 D$ & - & -0.039 & 0.002 & 0.032 \\
\hline 8 & & $h=0.05 D$ & - & -0.094 & -0.195 & -0.524 \\
\hline 9 & & $h=0.1 D$ & -0.005 & -0.331 & -0.627 & -1.402 \\
\hline
\end{tabular}

The mean deviations $\delta_{C p m}$ from Table 5 versus relative diameter $\beta$ of the orifice plate bore are presented in Fig. $4 a, b, c$. We can see from these figures that concentric protrusion upstream of the orifice plate with a height $h=0.025 D, 0.05 D, 0.1 D$ leads to a significant additional error in the discharge coefficient, which can be both positive and negative. Vertical error bar (I) in Fig. $4 a, b, c$ show range of deviation $\delta_{C p}$ for each value $\beta$, which corresponds to the range of change of Reynolds number during experiments (see Table 4 ).

These dependences of $\delta_{C p}$ on the design characteristics of the flow meter should be described with analytical expressions. Applying the method of extracting the influence of individual parameters and the method of least squares for coefficients determining, the authors obtained dependencies that adequately reproduce the experimental results presented in Fig. $4 a, b, c$ :

- for section length $L=2 D$ (see Fig. $3 a$ )

$$
\delta_{C p m}=\left(-51.2+34.2 \cdot e^{3.14 \beta}\right) \cdot(h / D)^{1.8} ;
$$


- for section length $L=5 D$ (see Fig. $3 b$ )

$$
\delta_{C p m}=\left(-4.8+1.88 \cdot e^{5.94 \beta}\right) \cdot(h / D)^{1.8}
$$

- for section length $L=10 D$ (see Fig. $3 c$ )

$$
\delta_{C p m}=\left(-5.9+3.24 \cdot e^{4.1 \beta}\right) \cdot(h / D)^{1.5},
$$

where $h / D$ is the relative height of the inner protrusion in the pipeline.

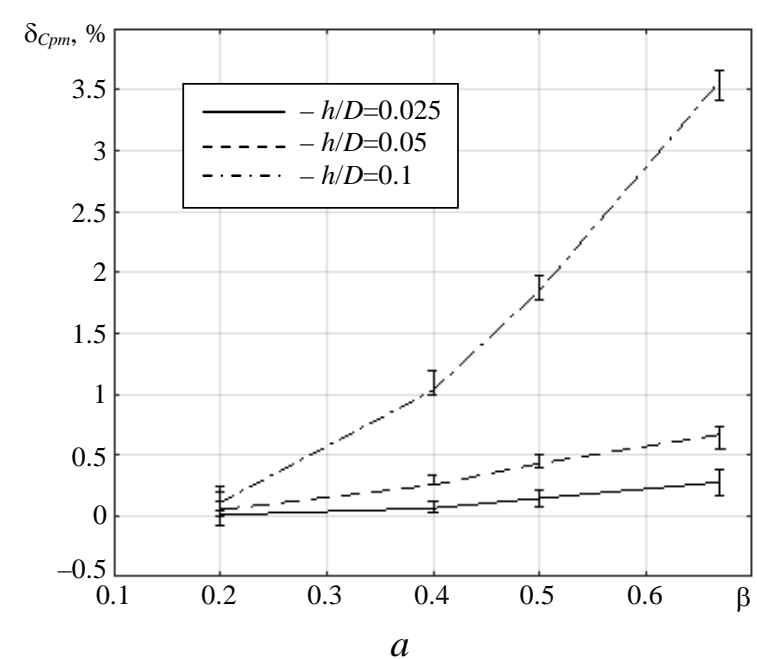

Fig. 4. The dependencies of mean deviation of discharge coefficient $\delta_{\text {Cpm }}$ versus relative diameter $\beta$ for the straight length of measuring pipeline between the face of carrier ring "+ " and the ring-imitator of protrusion: $L=2 D(a) ; L=5 D(b) ; L=10 D(c)$

Taking into that relative expanded uncertainty of measuring (calculating) the value at $95 \%$ confidence level is calculated by the formula:

$$
U_{y}^{\prime}=2 u_{y}^{\prime}=\operatorname{abs}\left(\delta_{y}\right) \text {, }
$$

we obtain a formula for calculating the additional relative expanded uncertainty caused by protrusion upstream an orifice plate:

$$
U_{h}^{\prime}=a b s\left(\delta_{C p m}\right),
$$
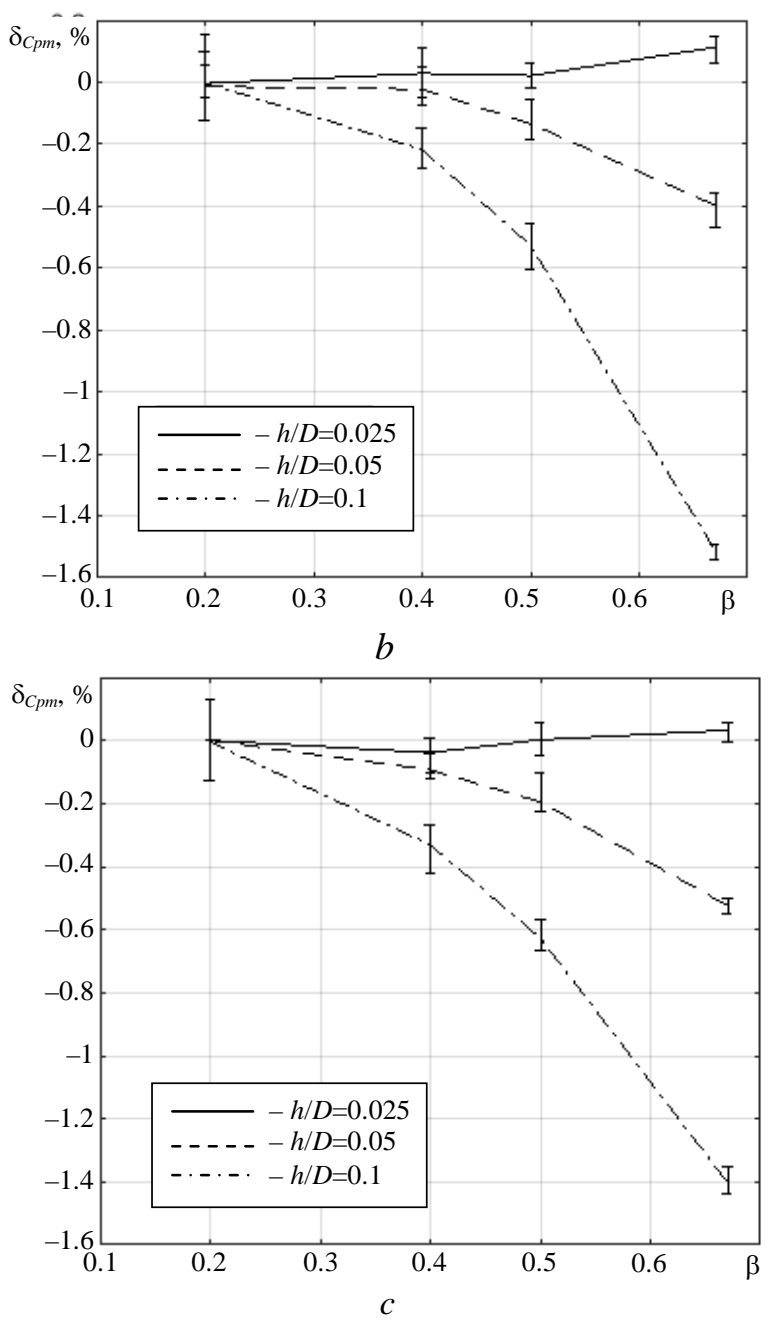

Therefore, using the dependencies (5) - (7) and (9) it is possible to evaluate the uncertainty $U_{h}^{\prime}$ for various relative diameter of orifice plate bore and relative height of protrusion for corresponding pipeline diameter.

\section{Conclusions}

According to the results of the performed researches the following conclusions were formed:

1) the concentric protrusion upstream an orifice plate leads to a change in the flow velocity profile and to a corresponding change in the orifice plate discharge coefficient; the module and the sign of the discharge coefficient change depend on the relative height of the protrusion and also its distance to the upstream face of the orifice plate;

2) the results of the experimental studies obtained for the rings imitating the height of the protrusion $0.025 \mathrm{D}, 0.05 \mathrm{D}, 0.1 \mathrm{D}$ indicate that significant additional errors in the flow measurement can occur 
even if the protrusion height equals $0.025 D$; particularly, for the relative diameter $\beta=0.67$ the additional error reaches the basic error of the pressure (pressure drop) transducers;

3 ) the dependence of relative deviation of discharge coefficient $\delta_{C p}=f(\mathrm{Re})$ is close to linear for the investigated values of the protrusion height $h$, the section length $L$ between the protrusion and the orifice plate and the relative diameter $\beta=0.2 ; 0.4 ; 0.5 ; 0.67$; the change in the value of $\delta_{C p}$ depending on the change in the number Re is insignificant, so the effect of the protrusion height for each fixed value of $h$ and $L$ can be reproduced by the mean deviation $\delta_{C p m}$;

4) the authors obtained analytical dependences (5) - (7) and (9), which make it possible to evaluate mean deviation of an orifice plate discharge coefficient, and also the additional uncertainty $U_{h}^{\prime}$ caused by concentric protrusion upstream the orifice plate for the corresponding values of the relative diameter, the relative height of protrusion and the pipeline diameter.

\section{Література}

1. Максимов М.В., Маслов, О.В., Писклова Т.С. Анализ эффективности управления энерговыделением водо-водяных энергетических реакторов. Труды Одесского политехнического университета. 2005. Вып. 2(24). С. 86-89.

2. Pistun Y., Matiko H., Krykh H., Matiko F. Structural modelling of throttle diagrams for measuring fluid parameters. Metrology and Measurement Systems. 2018. Vol. 25(4). P. 659-673. ISSN 0860-8229.

3. ДСТУ ГОСТ 8.586.5:2009. Метрологія. Вимірювання витрати та кількості рідини й газу із застосуванням стандартних звужувальних пристроїв. Частина 5. Методика виконання вимірювань (ГОСТ 8.586.5-2005, IDT). [Чинний від 01.04.2010]. Вид. офіц. Київ: Держспоживстандарт України, 2010. $196 \mathrm{c}$.

4. ISO/TR 12767:2007. Measurement of fluid flow by means of pressure differential devices - Guidelines on the effect of departure from the specifications and operating conditions (given in ISO 5167). [Publication date 09.2007]. $35 \mathrm{p}$.

5. Teyssandier R.G. The effects of symmetric steps and gaps on orifice measurement. The 4th North Sea Flow Measurement Workshop. Norway, Stavanger, November 5-7, 1985. 22 p.

6. Chakraborty G. Effect of various parameters on natural gas measurement and its impact on UFG. The 25th World Gas Conference. Malaysia, Kuala Lumpur, June 4-8, 2012. 12 p.

7. Orifice Metering of Natural Gas and Other Related Hydrocarbon Fluids, ANSI/API 2530, Second Edition. USA. 1985.

8. White paper on "Orifice meter installation configurations with and without flow conditioners" / Studzinski W., Karnik U., Lanasa P. et al. American Petroleum Institute. USA, Washington, 1997. 252 p.

9. Studzinski W., Weiss M., Attia J., Geerligs J. Effect of reducers, expanders, a gate valve, and two elbows in perpendicular planes on orifice meter performance. Flow Measurement 2001. Creating efficiency across industry sectors, international conference. UK, Peebles, May, 2001. 20 p.

10. Weiss M., Studzinski W., Attia, J. Performance evaluation of orifice meter standards for selected Tjunction and elbow installations. Proceedings of the 5th International Symposium on Fluid Flow Measurement. USA, Washington, April, 2002. 16 p.

\section{References}

1. Maksymov, M., Maslow, O., \& Piskolova, T. (2005). Analysis of the efficiency of energy release control of pressurized water reactors. Trudy Odesskogo politehničeskogo universiteta, 2(24), 86-89.

2. Pistun, Y., Matiko, H., Krykh, H., \& Matiko, F. (2018). Structural modelling of throttle diagrams for measuring fluid parameters. Metrology and Measurement Systems, 25(4), 659-673.

3. DSTU GOST 8.586.5:2009 Measurement of Flow Rate and Volume of Liquids and Gases by Means of the Standard Dierential Pressure Devices. Part 5. Measurement Technique (GOST 8.586.5-2005, IDT). [Publication date 01.04.2010]. Kyiv. National Organization for Standardization in Ukraine, 2010, 196.

4. ISO/TR 12767:2007. Measurement of fluid flow by means of pressure differential devices - Guidelines on the effect of departure from the specifications and operating conditions (given in ISO 5167). [Publication date 09.2007], 35.

5. Teyssandier, R. (1985). The effects of symmetric steps and gaps on orifice measurement. The 4th North Sea Flow Measurement Workshop. Norway, Stavanger, November 5-7, 1985, 22p. 
6. Chakraborty, G. (2012). Effect of various parameters on natural gas measurement and its impact on UFG. The 25th World Gas Conference. Malaysia, Kuala Lumpur, June 4-8, 12p.

7. Orifice Metering of Natural Gas and Other Related Hydrocarbon Fluids, ANSI/API 2530. (1985). Second Edition. USA.

8. Studzinski, W., Karnik, U., \& Lanasa, P. et al. (1997). White paper on "Orifice meter installation configurations with and without flow conditioners”. American Petroleum Institute. USA, Washington, 252 p.

9. Studzinski, W., Weiss, M., Attia, J., \& Geerligs, J. (2001). Effect of reducers, expanders, a gate valve, and two elbows in perpendicular planes on orifice meter performance. Flow Measurement 2001. Creating efficiency across industry sectors, International conference. UK, Peebles. 20 p.

10. Weiss, M., Studzinski, W., \& Attia, J. (2002). Performance evaluation of orifice meter standards for selected T-junction and elbow installations. Proceedings of the 5th International Symposium on Fluid Flow Measurement. USA, Washington. 16 p.

Матіко Федір Дмитрович; Matiko Fedir, ORCID: https://orcid.org/0000-0001-6569-2587

Костик Ігор Володимирович; Kostyk Ihor, ORCID: http://orcid.org/0000-0003-4553-595X

Матіко Галина Федорівна; Matiko Halyna, ORCID: https://orcid.org/0000-0001-5482-2307

Роман Віталій Іванович; Roman Vitalii, ORCID: https://orcid.org/0000-0002-8546-6752

Received January 15, 2020

Accepted February 21, 2020 